\title{
National Health Insurance: Realizing A Better Public Service and Guaranteeing the Citizens' Constitutional Rights
}

\author{
Agus Triono $^{1}$, Bayu Sujadmiko ${ }^{2}$ \\ \{agus.triono@fh.unila.ac.id¹, bayu.sujadmiko@fh.unila.ac.id²\} \\ Faculty of Law, Lampung University, Indonesa ${ }^{12}$
}

\begin{abstract}
National health insurance based on Law No. 24 of 2011 implemented on January 1, 2014 is a manifestation of the state's responsibility to fulfill the health care rights for all citizens. Nevertheless, this national policy has not been well received by the community. Not only because it has just started so that the service provided is not optimal, but also it is stated to contain elements of usury, which is contrary to Islamic law followed by a majority of the population in Indonesia. This article will discuss whether national health insurance is an alternative towards better public services or interventions of religious freedom, and how to implement a national health insurance program that can be well accepted by the whole community. National health insurance as an alternative in fulfilling the right to health care services has not been implemented optimally and even tend to discriminate against the poor people. It happens because of limited funding from both government and local governments influencing the lack of accessibility of the poor in this program. In addition, this program also contains an element of uncertainty, an element of gambling, and usury, which is contrary to the teachings of Islam. Therefore, the government should implement this program by using the excellent service standard as a general principle of the new public services and doing synchronization with Islamic law as the religious norms that followed by the largest population in Indonesia. It is important to protect the right in implementing the teachings of religion as a constitutional right.
\end{abstract}

Keywords: National Health Insurance; Public Service; Citizens' Constitutional Rights

\section{Introduction}

Health is a fundamental right which is the responsibility of the State to fulfill it. In Indonesia Constitution in Article $28 \mathrm{H}$ (1) states that every person has the right to live with physical and spiritual prosperity, residue, and get a good environment and healthy and receive medical care. Furthermore, in Article 34 (3) stated that the State is responsible for the provision of health care facilities and public service facilities. Therefore, the government as a public service provider must carry out this constitutional mandate without discrimination. In Law No. 36 of 2009 on Health, "health" means good health, both physically, mentally, spiritually and socially to enable more people to live socially and economically productive. According to this law, health development aims to increase awareness, willingness, and ability to live a healthy life for everyone in order to realize the degree of public health as high, as an investment for the development of human resources are socially and economically productive. 
Policies on health care through the national health insurance started on January 1, 2014 based on Law No. 24 of 2011 on Social Security Organizing Body will be an alternative in fulfilling the right to health for the community as a basic right of every citizen without exception. The goal or participants of this program are everyone, including foreigners who work for a minimum of 6 (six) months in Indonesia, which has been paying dues. So, the existence of a health insurance policy is expected to promote the establishment of better health care and to reach all citizens in Indonesia.

Nevertheless, in implementing health care we often encounter discrimination detrimental to the public service, especially the poor. The government efforts to provide health care to the poor through the national health insurance makes people difficult to access health services. Many patients on the national health insurance is only compounded by the administrative affairs of the membership to start taking care of the administration of health services at the health center. Poor communities often do not get a decent service and are discriminated against because of their low ability to pay. Several cases, including the case of disposal of a patient by some hospitals in Jakarta. This case occurred on January 5, 2019 when some patient using national health insurance card were refused by the hospital officer. (Lova, 2019) Furthermore, there are several cases of late treatment of patients that cause death. (Hutauruk, 2018) Some similar cases in the other areas are also happens. It shows poor health services and discrimination against the poor people who cannot afford the cost of the treatment. Even after the launch of the health care insurance program, though, even more cases of neglect of poor patients who use a national health insurance card.

The cases that occurred showed that health programs initiated by the government is still far from the expectations of society. In addition, another controversy is about the status of the national health insurance that is not in accordance with the principles of Islam, especially problematic considering that the people of Indonesia are predominantly Islamic. Incompatibility of national health insurance program with the principles of Islam as the opinion or fatwa of Indonesian Ulema Council stating that the national health care insurance system applied contains an element of uncertainty, gambling and usury are contrary to the teachings of Islam causing a lack of public acceptance. However, the government did not seem to care about the interests of the majority community. The absence of alternative insurance policy on national health insurance, according to the teachings of Islam and the obligation to participate in this program can be considered as government interference in the free exercise of religion as part of the religious freedom which is also guaranteed by the constitution. These problems are then interesting to be discussed as to whether the national health insurance is an alternative to the better services or even the intervention of religious freedom in Indonesia.

\section{Method}

This study is a normative legal research using a statue and conceptual approach. The statute approach is to analyze various regulations on the national health insurance. The conceptual approach is used to answer the problems on how the implementation of national health insurance in the community. 


\section{Results and Discussion}

\subsection{The Role of Government in Realizing a Better Health Service}

Health is a human right that must be fulfilled and protected by the Government. In addition, health is also one indicator of public welfare in a country. With fulfilled and protection of health services for the people it will have implications for improving the productivity of society and can reduce State expenditure in the health sector so that the state budget can be optimized in the areas of strategic development that leads to prosperity. The right to health care is one of the rights to welfare. Economic rights, social and cultural human rights are the type associated with material prosperity, sociality and culture. These kinds of rights are originally set forth in article 16, 22 to article 29 of the Universal Declaration of Human Rights, and further stipulated in the International Covenant on Economic, Social and Cultural Rights (ICESCR), 1966. The rights are included in the category economic, social and cultural rights is one of them is enjoying the standard of physical and mental health are high.

Article 2 (1) of the Covenant states that any State party to the present Covenant undertakes to take steps, both individually and through international assistance and cooperation, especially technical and economic assistance, up to the maximum of its available resources, with a view to achieving progressively the full realization of the rights recognized in the Covenant using all adequate facilities, including taking legislative measures. This Covenant indicates that the State duty is not only to actively take action, but also take certain measures to protect the rights of its citizens. Indonesia has ratified the ICESCR in 1966 by Law No. 11 of 2005 and should take action in providing better health services. The right to health in fair, equitable and non- discrimination is also in accordance with the values of the Pancasila as the state philosophy, especially in verse 5 stating that social justice for all Indonesian people. Social justice in this case also includes equity in gaining access to good health and without any distinction based on social status in society.

In the constitution of the Republic of Indonesia and the Law No. 39 of 1999 on the Human Rights, has set up the same thing in Article 71 that the government is obliged and responsible to respect, protect, uphold and promote human rights stipulated in this Law, regulations other legislation and international law on human rights ratified by the Republic of Indonesia. Article 72 states that the government's obligations and responsibilities include the implementation of effective measures in the areas of legal, political, economic, social, cultural, defense and security, and other fields. Indonesian government's efforts to achieve better health services appear on the amount of regulation that supports it. However, in practice, there are many obstacles in the field faced particularly in implementing the regulation. As we know that the budget funds allocated to the health sector until 2015 are only around $2 \%$, while according to the provisions of Article 171 (1) of Law No. 36 of 2009 on Health requires the government budgeted as much as $5 \%$. It is also still far from other countries in Southeast Asia that have been budgeted sufficiently high public health costs, such as Malaysia, Thailand, and TimorLeste which have been budgeted at 12 percent health.

According to the law on local government, health affair is obligatory functions of local government that can be carried out jointly with the government. The local government should allocate a budget for health affairs at least $10 \%$ of the total budget expenditure excluding salaries. But the facts show that based on data from 2012 there were only 11 provinces that allocate budgets for health above $10 \%$ for health. These provinces are Aceh, Babel, Banten, West Java, Central Java, Yogyakarta, East Java, Gorontalo, Sulawesi, Bali, Jakarta. Based on these data, it appears that most of the provinces in Indonesia have not accommodated health matters as an obligation of the local government. Moreover, in practice it appears that the 
national health insurance program has not been able to cover all levels of society, especially the poor, because in 2015 the public participation in the new national health insurance only covers $60 \%$ of the 250 million people in Indonesia. Administration difficulty for citizens to get a national health insurance card is visible from the fact that there are $40 \%$ of the population who have not been registered under the national health insurance.

In practice, health care providers have not been oriented to good service to the community, they are still busy with the paperwork so that ignore the rights of patients. This happens because not all hospitals, both public hospitals and private hospitals have cooperated with the national health insurance agency guaranteeing the costs of treatment, so they are very concerned about the costs to provide services to the poor. Moreover, differences in grade and service facilities applied also led to discrimination in delivering healthcare services. All these facts indicate that the government's commitment in realizing health care services for the people has not been reflected in the national health insurance program. Application of the insurance system in the national health insurance impress a hands-off government action in the health sector, which is the constitutional right of the citizens who should be the responsibility of the government. Implementation of the national health insurance program enlarges the space discrimination and have not led to better public services.

\subsection{Government Policy and Intervention on Religious Freedom}

The government policy to implement a national health insurance program using the insurance system in which the entire society is required to be participants started on January 1st, 2014 and 2015 according to the Chairman of the National Social Security Council Chazali H. Situmorang, in Banjarmasin, has reached 150 million people, and it is becoming the largest in the world. Law No. 24 of 2011 explained that the participants of the national health insurance are that everyone, including foreigners who work for a minimum of 6 (six) months in Indonesia, which has been paying dues. As a national program that covers all Indonesian citizens and foreigners as the provisions of the legislation, national health insurance policy should also take into consideration the interests of the people both in terms of product quality and level of public acceptance. In the view of Islam, halal status and benefits of a product is an important element that should be considered include the national health insurance system implemented by the government. The argument about the benefits of this policy may be acceptable, but with non-adherence to the teachings of Islam, it becomes a problem for Muslims as the majority of the population in Indonesia.

As we know that the Indonesian Ulema Council has given the view that a national policy on health insurance organized by the Agency for social health insurance carrier does not comply with Islamic law. Chairman of Fatwa of the Indonesian Ulema Council confirmed the existence of a fatwa declaring that the national health insurance does not conform to Islamic law. This fatwa is a consensus decision or forum Fatwa Committee meeting in Boarding Schools At-Tauhidiyyah Cikura, Bojong, Tegal, Central Java, 8-10 June 2015. The Fatwa of the Indonesian Ulema Council stated that the national health insurance system is not in accordance with Islamic law because it is considered to contain gharar (uncertainty), maisir (gambling) and riba (usury). Other reasons, participation in the national health insurance is also considered to be unfair because they discriminate background of participants.

According to the Indonesian Ulema Council, the implementation of national health insurance is considered not in accordance with Islamic principles because it contains elements gharar (vagueness), gambling (having elements of betting), and usury. In turn, the contract is not clear which will lead to gambling. More specifically, in Arabic, al-maisir have meaning: "to obtain something very easily without any hard work or earn a profit without working." 
While usury can be seen from the $2 \%$ penalty for late payment of the national health insurance contributions. The commission fatwa of Indonesian Ulema Council then makes a number of recommendations addressed to the government as follows:

1. The government should create minimum standards or decent living standard in terms of health insurance that is applicable to every resident as a form of public service as the basic capital for the creation of a conducive atmosphere in society regardless of their background;

2. The government should establish rules, systems, and format of national health assurance providers to conform with Islamic principles.

In the legal system of Indonesia, the fatwa of The Indonesian Ulema Council does not have binding legal force, but this fatwa is very important to be a reference in making policies that will have implications for the entire society in Indonesia are mostly Muslim. If we see references used by The Indonesian Ulema Council, this means that the government should hold an insurance program to follow directions or fatwa that Muslims avoid the dangers and evils, because the fatwa was already decided before the national health insurance program. Because if the government ignored the recommendations of the Indonesian Ulema Council, which represents the interests of the majority of people, it will make the loss of many people and indicates that the government has intervened in the freedom to practice religion as a part of religious freedom.

Guaranteeing the protection of religious freedom from interference and abuse of power by the government is the essence of the concept of humanity (or fundamental) rights that has been accepted as a general principle. This has been confirmed in various international human rights instruments. Article 18 of the Universal Declaration of Human Rights, International Covenant on Civil and Political Rights provides the basis for rights that everyone is entitled to freedom of thought, conscience and religion. The article consists of four principal; first, everyone is entitled to freedom of thought, conscience and religion includes the freedom to establish a religion or belief of his choice, and freedom, either alone or jointly with others, whether in public or closed, to practice religion and belief in the activities of worship, observance, practice and teaching. Second, no one can be forced so disturbed liberty to adopt or establish a religion or belief of his choice.

Third, the freedom to manifest one's religion or belief may only be restricted by legal regulations, and are necessary to protect public safety, order, health, or morals or the rights and fundamental freedoms of others. Fourth, the state party promises to respect the liberty of parents and, when applicable, legal guardians, to ensure that the religious and moral education for their children in accordance with their own convictions.

Indonesia is one of the countries that ratified the international covenant through Law No. 12 of 2005 on the Ratification of the International Covenant on Civil and Political Rights. Indonesian Constitution also guarantees the right to freedom of religion or belief, the right to protection from discriminatory actions and equality before the law. Article 28 of the Indonesian Constitution states that freedom of religion is a human right that cannot be reduced under any circumstances. Furthermore, the Law No. 39 of 1999 on Human Rights, Article 4 mentions that the freedom of religion, is a human right that cannot be reduced under any circumstances and by anyone. Described in Article 22 that everyone is free to embrace their religion and to worship according to their religion or belief was, and the state guarantees the freedom of every person to embrace their religion and to worship according to their religion or belief was.

So, in the context of protection of the right to freedom of religion or belief, there are various regulations which oblige states to protect freedom of religion or belief, without any 
discrimination through laws and policies that guarantee in accordance with the Covenant, including policy of public health insurance program.

\subsection{Realizing an Acceptable National Health Insurance}

Indonesia is the rule of law in which government and communities should uphold the rule of law as part of the development of law. But it is undeniable that the development of the law has caused an atmosphere asymmetry between law and society laden with injustice and inequality in social, economic, and political. Inequality between the legal and social conditions manifested in the form of powerlessness, isolation, vulnerability, security, and sustainability of livelihood. This occurs as a result of differences in religious beliefs, ideology, legal culture, political interests grow and thrive in a community. In addition, in certain cases between a community with other communities in conducting activities to meet their needs to have elements in common when it made the Qur'an and Hadist as signposts in activities to meet their needs. Signs settings in the activity in question, either in the form of banking law, selling, insurance, mortgage, debts, as well as in other forms in the field of economic law or sharia economics.

There are three reasons that cause an imperfect correlation between the law and the norms/ social value. First, although the law is often regarded as the relation of social norms and values, the formal legal system may be too slow in adapting to changes in the social norms and values of society. Second, the legal system is based on consistency, while the norm might be contradictory. Third, the community may tolerate certain behavior, but does not want the behavior listed in the rule of law. Thus, it is very natural that there is a difference of views between positive law with the law adopted by the public as in the implementation of national health insurance program. But the general principle is that the State must guarantee the rights of every citizen in a fair and equitable manner.

In the modern legal system, equity is a principle that is fundamental to create prosperity. According to Oscar Schachter, the use of equity can be divided into five, namely; a) Equity as a base individualization of justice is meant to dilute the rigid law. b) Equity as a basis for the use of the principle of fairness, reasonableness, and trust or good faith. c) Equity as a basis of certain principles contained in legal reasoning connected with fairness and reasonableness, d) fair standards for the allocation and distribution of resources and benefits. e) Equity broadly as a synonym for the concept of distributive justice, which is used to justify the request arrangements and economic and social distribution of the wealth.

In the context of the implementation of the national health insurance policy, the State should not only achieve justice for all citizens, but should also avoid actions that lead to the intervention of human rights. Implementation of this concept is that the State is required to integrate the various interests, including laws or norms developed in the community in formulating national policy implications, because it will determine the level of public acceptance. So, the regulation is made also must obtain legitimacy from the people. Suchman said that "Legitimacy is a generalized perception or assumption that the action of an entity is desirable, proper or appropriate within some socially constructed system of norms, value, believed, and definitions. Johnson et al explained that the legitimacy of the collective construction of social reality. Legitimacy based on the norm is adherence to the norms and values that are accepted widely and informally.

According to Syaukani and Thohari, when the law was built on a foundation that is not in accordance with the spiritual structure of society, we can be sure that the people's resistance to that law will be very strong. Hart also argued that the existence of a legal system is a social phenomenon which always presents two aspects. These aspects include the attitudes and 
behavior as a recognition of the regulations and also the attitude and behavior of more simple such as compliance or acceptance. With the recognition embodied in the attitudes and behavior, this means that a rule of law can be accepted by society and has achieved complete form in the sociological aspects.

To achieve national health insurance that can be accepted by everyone, the government also has to accommodate the participation of the community that contains the values of kindness. In the actual contexts, those values are the quality of services as a general principle in the new paradigm of public services and the system avoided from uncertainty, gambling and usury as the religious norms. In fact, Law No. 36 of 2009 on Health has also set them properly. Article 2 states that the health system is based on the principles of humanity, balance, benefits, protection, respect for rights and obligations, justice, gender and nondiscriminatory and religious norms. These principles are described below:

1. The principle of humanity means that health development must be based on humanity which is based on the Almighty God by not distinguishing religious groups and nations.

2. The principle of balance means that health development should be implemented between the interests of individuals and society, between physical and mental, as well as between the material and spiritual.

3. The principle of benefits means that the development of health benefits should provide maximum benefits to humanity and healthy livelihood for every citizen.

4. The principle of protection means that health development should be able to provide protection and legal certainty to providers and recipients of health services.

5. The principle of respect for the rights and obligations means that health development by respecting the rights and obligations of the community as a form of equality before the law.

6. The principle of justice means that the organization of health services should provide fair and equitable to all walks of life with affordable financing.

7. The principle of gender and non-discriminatory means that health development does not differentiate treatment of women and men.

8. The principle of religious norms means healthy development must consider and respect and do not distinguish between the religious affiliations of the people.

In the implementation of the above principles, government administrators should be able to increase their ability to formulate and implement policies that have implications for the society at large. Increasing the ability of the government administrators will expand the public arena to make the choice of goods and services available. Furthermore, these conditions will contribute to the realization of the individual value and the public welfare. In this context, it is clear that the people should also participate actively and be allowed to submit their aspirations either individually or in groups to the government when there is a policy that does not fit or even violate the rights of society. Public participation is a manifestation of openness and inclusiveness that are the values of democracy and a key component of the legitimacy of democratic government.

When people realize the importance of participation in the government program and the government wants to open up space public participation, the government policies will have a strong legitimacy since the decision to take the policy also deals with the problems of society itself, including in the national health insurance policy. So, the national health insurance program as a grand design in fulfilling the citizen constitutional rights can lead to better public services and free from the intervention of religious freedom. 


\section{Conclusions}

Based on the discussion above, it can be concluded that the implementation of a national health insurance policy which began on January 1st, 2014 has not led to better public services. Health care providers have not been oriented to the fulfillment of the right to health care but are still preoccupied with the problems of administration and finance. In addition, the national health insurance system has not accommodated the religious norms as one of the principles in health development. As a government policy that requires all Indonesian citizens to be participants, incompatibility with the principles of Islam as a doctrine professed by the majority of Indonesia's population is a form of intervention in the freedom to practice religion as a part of religious freedom. Therefore, to achieve national health insurance that can be received well by all the people, the government should use the excellent service standard oriented to the fulfillment of the right to public health services and synchronize with religious norms adopted by most of Indonesian people to gain legitimacy and the high acceptance rate of the whole society.

\section{References}

[1] D. Salskov-Iversen, "Environmental Sustainability Strategy and City Government," Dev. Strateg. Public Manag., pp. 211-226, 2014.

[2] Ali, Zainuddin. (2008). Hukum Ekonomi Syariah, Jakarta: Sinar Grafika.

[3] Denhardt, Janet V. and Robert B. Denhardt. (2007). The New Public Services: Serving, Not Steering, New York: M.E. Sharpe Inc.

[4] Dowling, J and J. Pfeffer (1975). Organisational Legitimacy: Social Values and Organisational Behavioir, Pacific Sociological Review, Vol. 18, Iss.1.

[5] Hart, H.L.A. (2009). Konsep Hukum, Bandung: Nusamedia.

[6] Johnson, Cathryn, T. J. Down, and C. L. Ridgeway. (2006). Legitimacy as a social Process, Annual Review of Sociology, Amsterdam: Elseiver JAI.

[7] Malanczuk, Peter. (1997). Akehurt's Modern: Introduction to International Law, New York: Routledge.

[8] Scott, W.R. (2003). Organizations: Rational, Natural and Open Systems, 5th edition, New Jersey: Prentice Hall.

[9] Sen, Amartya. (1999). Development as Freedom, NewYork: Anchor Books.

[10] Syaukani, Imam dan Ahsin Thohari. (2008). Dasar-Dasar Politik Hukum, Jakarta: Raja Grafindo Persada.

[11] Schachter, Oscar. (1991). International Law in Theory and Practice, Dordrech: Martinus Nijhoff Publishers.

[12] Suchman, Mark, C. (1995). Managing Legitimacy: Strategies and Institutional Approach, Academy of Management Review, vol. 20, (3).

[13] Tisnanta, H.S. and Agus Triono. (2013). Progressive Local Regulations: An Alternative to Fulfillment of Poor People Rights of Health in Local Autonomy, International Proceeding on Law, Business, and Governance, Icon-LBG, Bandar Lampung University, Lampung.

[14] https://megapolitan.kompas.com/read/2019/01/05/17232111/rumah-sakit-yadika-tolak-pasienbpjs-warga-kecewa?page $=$ all, last accessed on June 10, 2019

[15] https://indopos.co.id/read/2019/01/05/160751/banyak-ditolak-rumah-sakit-pasien-butuh-solusisoal-bpjs, last accessed on June 10, 2019

[16] https://medan.tribunnews.com/2018/01/26/viral-pasien-ditelantarkan-meninggal-di-rs-adammalik-berikut-penjelasan-dokter, last accessed on June 10, 2019 
[17] https://medan.tribunnews.com/2018/01/23/pasien-sekarat-meninggal-dunia-ditelantarkan-pihakrumah-sakit-di-medan-videonya-viral last accessed on June 10, 2019

[18] https://www.hukumonline.com/berita/baca/lt4ed6f3c486402/minimnya-anggaran-kesehatanlanggar-hak-rakyat, last accessed on June 11, 2019 